Lektor

Institut for Kunst- og Kulturvidenskab, Københavns Universitet

\title{
HANDELSORIENTALISME I ENGELSK DRAMA 1580-1630
}

Englands voksende engagement i den oversøiske handel i slutningen af 1500-tallet og begyndelsen af 1600-tallet sætter sig tydelige spor i tidens drama. Jo større import fra Orienten (Det Osmanniske Rige og Mogul Indien), jo flere fjerne mediterrane geografier i de skuespil, som opføres på Londons teaterscener. Scenens magiske evne til at fordoble sig i et aktuelt her og et fiktivt dér bliver udnyttet fuldt ud til at fremstille den store verden, hvorfra stadigt flere søfolk, merchants, frigivne slaver og rejsende vender hjem med varer og beretninger. Her skal det handle om en gruppe dramaer, hvis handling udspiller sig inden for Det Osmanniske Riges grænser - eller tæt på disse - og hvori kristne handelsfolk, jøder, renegater, tyrkere og pirater spiller hovedrollerne: De engelske "tyrko-barbareske" dramaer som f.eks. Christoffer Marlowes The Jew of Malta (1589), Robert Dabornes A Christian Turned Turk (1612) og Philip Massingers The Renegado (1630). Heri kolporteres en gammel fordom om handelslivets aktører, ifølge hvilken the merchants kun arbejder for deres egen fordel og ikke for det fælles bedste, "the common-wealth". Det særlige ved de tyrko-barbareske dramaer er nu, at de kobler denne fordom med samtidens udbredte frygtforestillinger om islamisk-religiøs afsmitning og tyrkisk invasion. Den historiske baggrund for disse frygtforestillinger var på den ene side Det Osmanniske Riges eks- 
pansion og på den anden side barbaresk-staternes pirater, der ikke bare plyndrede handelsskibene, men også solgte deres besætning som slaver. En ikke ubetydelig procentdel af de kristne slaver i Nordafrika valgte at konvertere til islam.

De engelske tyrker-dramaer har været genstand for en omfattende granskning i de forgange 15 år. Studier som Daniel Vitkus' Turning Turk: English Theater and the Multicultural Mediterranean, 1570-1630 (2003), Matthew Dimmocks New Turkes: Dramatizing Islam and the Ottomans in Early Modern England (2005), Companion to the Global Renaissance. English Literature and Culture in the Era of Expansion (red.: Jyotsna Sing, 2007), Barbara Fuchs' Mimesis and Empire (2009), Early Modern England and Islamic Worlds (red.: Linda McJanette og Andrea Bernadette, 2011) repræsenterer nogle af de vigtigste undersøgelser i så henseende. Heri studeres repræsentationer af muslimer, jøder, krydskulturel mobilitet og ditto udveksling ud fra post-kolonial teori og i lyset af historiske kontekster, der har med handel, krig og imperiedannelse at gøre. Samtidig med at min tilgang informeres af disse studiers brede historiske og globale perspektiv, forsøger jeg at relatere de omtalte skuespils fremstillinger af kristne, tyrkere, renegater og jøder til en mere fokuseret problemstilling: Spændingen mellem the merchant og the common-wealth. Ordet "merchant" var forbeholdt den handelsmand, som ikke bare levede af det hjemlige marked, men også af import fra og eksport til udenlandske markeder (Finkelstein 25). The merchant var derfor en social type, hvis lydighed og troskab over for kirken, kongen og det politiske legeme man nemt kunne drage i tvivl (Games 96). De skuespil, vi skal kigge på nedenfor, har alle placeret the merchant et sted i eller tæt på den islamiske verden, og hvis han i det ene tilfælde er gudløs, så fristes, lokkes og forføres han i de to andre tilfælde af islam.

\section{MERCHANT-BASHING OG HANDELSKOMPAGNIER MED KONGELIGT MONOPOL}

"Merchants", står der i en anonym pamflet fra 1530'erne, tænker kun på at "købe og sælge og tilrane sig mammon [riches] fra det fælles bedste." Flere år senere, da England i 1620'erne rammes af en handelskrise, karakteriserer Robert Burton i Anatomy of Melancholy (1621) verden som en markedsplads, 
hvor "enhver [kun] tænker på sig selv, sine personlige ["private"] mål og vogter over sit eget" (Finkelstein 22). Baggrunden for den udbredte mistænkeliggørelse af the merchant i det tidlig moderne England hænger sammen med, at han står uden for det traditionelle jordbaserede standshierarki. The merchant er hverken vasal eller herre, han betaler ikke tribut til en herre og arbejder kun for sig selv og for sine egne mål. I en tid, hvor samfundet stadigvæk tænkes i legemets, kosmossets og hierarkiets billeder, hvor alt og alle således har deres 'rette plads', og hvor den enkelte kun er noget i kraft af den helhed, som hovedet/solen/kongen regerer over, er det svært at se "den handlendes selv-orientering" som noget positivt (Finkelstein 25).

Denne spænding mellem den private interesse og det fælles bedste manifesterer sig også i handelskompagniernes tilblivelse, opbygning og finansiering. Det er således på opfordring fra en gruppe londonske købmænd, at dronning Elizabeth - den principielle garant for det fælles bedste - i 1580 iværksætter en ihærdig diplomatisk indsats for at få den tyrkiske sultan til at underskrive en handelsaftale. Indsatsen bærer frugt. I 1581 oprettes The Turkey Company, i 1582 The Barbary or Marocco Company, og i 1592 fusionerer de to handelskompagnier i The Levant Company. I 1600 stiftes endvidere The East India Company, der handler med Mogul Indien uden om tyrkernes mellemkomst. I 1606 grundlægges The Charter of the Virginia Company of London. I det omfang den engelske merkantile orientalisme opstår på baggrund af den tidlige handelskapitalisme, er det ikke kun dennes generelle internationaliserings- eller globaliseringseffekt, der har betydning. De kongeligt chartrede handelskompagnires karakteristiske alliance mellem private og statslige interesser udgør også en vigtig baggrund for forståelsen af det særlige ved denne orientalisme.

Til forskel fra de gilder eller laug, som tidligere havde styret handelen, var The Levant Company og The East India Company ikke uafhængige af kongemagten. De var ganske vist finansieret af private investorer, men var samtidig afhængige af statslig good will og beskyttelse, hvilket de kvitterede for ved at påtage sig statslige opgaver som f.eks. at rekruttere og finansiere ambassadører. Det at balancere mellem statslige og private interesser bliver således et centralt kendetræk ved handelskompagnierne (Eriksson og Assenova 3). Det kongelige charter forsynede desuden handelskompagnierne med en udstrakt frihed til at iværksætte diverse koloniale og handelsmæssige tiltag, 
hvilket betød, at Englands globale ekspansion skabtes af mere eller mindre autonome og private aktører, der var drevet af eventyrlyst, iværksætterånd, nysgerrighed og økonomisk interesse (Eriksson og Assenova 8).

Handelskompagniernes finansieringsform lagde på den måde grundstenen til et imperium, der - til forskel fra det spanske - ikke var baseret på en central kongemagt, men på investorer, handelsfolk, eventyrer, soldater, guvernører, præster, rejsende og diplomater. Det er denne iboende spænding mellem stræbsomme, selvrådige og horisontalt ekspansive individer på den ene side og kongemagtens 'hierarkiske' krav (Thurn 162) på den anden side, som opsnappes og stilles til skue i de tyrko-babareske dramaer.

\section{DET FÆLLES GULD OG TYRKERNE}

Barabas i The Jew of Malta lever ikke kun op til tidens fordomme om jøder. Han personificerer også de fordomme, der omgav den internationale handelsmand. Jødens formue stammer fra import af persiske, arabiske, græske og mauriske varer, som han eksporterer videre til "Antwerpen, Firenze og Sevilla, / Venedig, Moskva, London, Lübeck, Frankfurt...", hvor han således har"...skyldnere/Og også penge liggende i banken" (Marlowe 187). Barabas økonomiske eller merkantile interesser går på tværs af de nationale og religiøse grænser, hvilket hans jødiske identitet naturligvis skal understrege. Ingen følelse af forpligtelse eller loyalitet knytter ham til Malta.

Marlowe har hentet inspiration til The Jew of Malta i tyrkernes belejring af øen i 1565. Selvom det insulære England ikke havde grund til at frygte de fremstormende tyrkere, skabte begivenheden alligevel stor furore. Et sted bad menigheden Gud om at standse "de vantros vrede og vold", der truede med at "udrydde" den sande tro, frelserens minde og hele kristenheden. Biskoppen af Canterbury dekreterede, at der tre gange ugentlig skulle læses en bøn i alle bispedømmets kirker, og heri bad man Gud om at standse "de bemeldte vilde og mest grusomme Tyrkeres indtrængen og invasion der udgør den skrækkeligste fare for hele kristenheden" (Vitkus, "Turning Turk in Othello": 147-48). Mens tyrkerne ikke havde held til at erobre Malta, havde de til gengæld succes med deres militære ekspansion i Østeuropa. Gennem de sidste tre årtier af 1500-tallet ankom der således en lind strøm af efterretninger om tyrkernes militære sejre på Balkan og 
i Middelhavet (Vitkus, "Turning Turk in Othello" 148), hvilket naturligvis også var medvirkende til, at Maltas belejring endnu var i levende erindring, da Marlowe i 1580'erne skrev The Jew of Malta.

Marlowes drama afviger naturligvis fra de historiske begivenheder og forhold på flere punkter. Således har han opdigtet en tyrkisk-maltetisk traktat, ifølge hvilken det kristne Malta har status som skattepligtig vasalstat til sultanen i Konstantinopel. Handlingen skydes i gang, fordi øen har forsømt at betale den årlige skat, hvorfor en tyrkisk krigsgalejflåde under sultanens søn Selim Calymaths kommando er ankommet. Da senatet ikke råder over det skyldige beløb, beslutter guvernør Ferneze, at øens velhavende jødiske købmænd, deriblandt Barabas, skal afstå halvdelen af deres formue for "... derved fra ruin at frelse mængden...", som Ferneze udtrykker det, idet han fortsætter: "Lad hellere én lide for det fælles / End mange må fortabes for den ene..." (Marlowe 49). Den i mere end en forstand 'vantro' jøde bliver med andre ord - $\mathrm{i}$ øvrigt under trussel om tvangskristning - bedt om at ofre halvdelen af sin private formue for at redde Malta mod at blive annekteret af tyrkerne. I senatets krav til den driftige handelsmand ses en illustration af den blanding af "vertikal kontrol og horisontal ekspansion", som kendetegnede den tidlige handelskapitalisme (Thurn 157). Den 'vertikale' statslige konfiskering af jødens private formue, erhvervet gennem en omfattende og stadigt ekspanderende oversøisk handel, formuleres imidlertid på en sådan måde, at i hvert fald visse dele af publikum ville høre et ekko af Johannes Evangeliet 11:50-53, hvor ypperstepræsten Kajfa argumenterer for henrettelsen af Jesus med disse ord: "I tænker heller ikke på, at det er bedre for jer, at ét menneske dør for folket, end at hele folket går til grunde.." (Marlowe 148). The Jew of Malta forherliger i det hele taget på ingen måde det senat, der, med henvisning til det fælles bedste, kræver, at jøden ofrer sin formue. Senatet har kompromitteret sig ved at underkaste sig sultanen: "Har Maltas riddere en pagt med tyrken / Endda erhvervet æreløst for guld?" (Marlowe 89), spørger den spanske viceadmiral Martin del Bosco, da han ankommer til øen, som hans konge, den tysk-romerske kejser Karl V, både i fiktionens og virkelighedens verden har skænket Malteserordenen, efter at denne i 1522 mistede Rhodos til tyrkerne. At forsvare sig mod den kristne verdens ærkefjende gennem vasalrelationens underkastelse kaster naturligvis skam over Maltas senat. 
Men skuespillet delegitimerer også senatets konfiskering af Barabas' formue på en anden måde. Med reference til Marx' skrift "Om jødespørgsmålet" (1843) gør Stephen Greenblatt opmærksom på, at Barabas' begær efter guld i virkeligheden svarer til "...den brændende lidenskab som ulmer i alle karaktererne" (296). Datterens friere, øens prostituerede, senatet og Maltas munkeordener jagter alle Barabas' guld. Hvis der findes noget fælles blandt Maltas indbyggere, består dette i den egoisme og grådighed, som jøder og kristne, borgere og prostituerede alle lægger for dagen - og som de i øvrigt har til fælles med tyrkerne jf. dette replikskifte mellem Maltas guvernør og den tyrkiske pasha Callapine:

Ferneze:

Velkommen. Hvordan går det Calymath [den tyrkiske sultan]?

Og hvilken vind har nu ført jer til Malta?

Callapine:

Den vind som også driver hele verden:

Begæret efter guld

(Marlowe 167)

Hvis "mængden" alligevel blot består af enkeltindivider drevet af det samme egoistiske begær efter guld, findes der ikke umiddelbart andre 'værdier' at forsvare mod tyrkernes invasion end muligheden for at forfølge dette begær. Sigende nok nævner Ferneze da også kun én ulempe ved versalforholdet, nemlig at det tvinger senatet til at nedlægge forbud mod salg af tilfangetagne tyrkere på det maltesiske slavemarked.

IThe Jew of Malta udlignes forskellen mellem den kristne og den muslimske verden af den økonomiske tænkning. At kristne, jøder og tyrkere fremstilles som lige besatte af guld udjævner i det hele taget de dikotomier og hierarkier, som datiden normalt tænker forholdet mellem disse tre religioner i. Når Marlowe gør jagten på guld til tyrkernes primære drivkraft for at søge større dominans i Middelhavet, går han endvidere imod den generelle fortolkning af tyrkernes ekspansion som et bevis på deres djævelske vilje til at udbrede den islamiske tro til hele verden. På den måde modsiger skuespillet to udbredte forestillinger i datidens opfattelse af forholdet mellem den kristne og den muslimske verden: For det første at der var tale om a clash of civilisation; for det andet at tyrkerne repræsenterede 
en trussel mod kristendommen. Hos Marlowe er tyrkerne interesseret i guld, ikke i at udbrede deres tro.

The Jew of Malta fremmaner en verden, hvori regenters og private aktørers på en og samme gang økonomiske og territoriale interesser overtrumfer moralske værdier, en verden hvori det at tænke individer, lande og imperier som religiøse fjender, der har forskrevet sig til falske profeter og Kristi mordere, forekommer irrationelt, fordi disse såkaldte fjender i virkeligheden er rivaler, allierede, konkurrenter eller partnere i den store jagt på lukrative handelsaftaler, sikre handelsveje og ædelmetaller. Hvis man vil klare sig i denne verden, kan man ikke kun leve blandt sine arts- og trosfæller - alle må i en vis forstand blive som jøderne:

Barabas:

Det siges at vi er et splittet folk;

Det er vi måske nok, men vi har samlet

Langt mere rigdom end de hellige.

I Grækenland bor Kirriah Jairim,

Obed i Bairseth, Nones i Portugal

Jeg selv på Malta, nogle i Italien,

I Frankrig mange, alle er vi rige -

Ja, meget rigere end nogen kristen.

(Marlowe 33)

I en sådan verden bestemmer den økonomiske interesse - og ikke troen hvem man slutter venskab med:

Barabas:

Og sådan går det rundt og rundt i ring.

Jeg elsker ingen [hverken tyrkerne eller de kristne], lever med dem begge,

Og tjener penge på min listighed;

Og han som giver mig den største fordel

Han er min ven.

(Marlowe 259)

Barabas ligner et grotesk billede af det mind set, som handelskompagnierne brugte kræfter på at udvikle hos de folk, som sendtes ud i handelsstationernes internationale samfund (Games 89-99). Selvfølgelig var alle former for etnisk og religiøst betinget angst eller had uhensigtsmæssige for sådanne handelsfolk (Games 89-99). Selvfølgelig var det vigtigt for en 
handelsmand at være i stand til at se handelsmanden - og ikke ærkefjenden og den vantro - i tyrkeren. De fremmedkulturelle færdigheder og krydskulturelle identifikationer i den økonomiske gevinsts navn betød imidlertid samtidig, at handelsfolk blev opfattet som værende i overhængende fare for - som man sagde - "to turn Turk".

\section{PIRATER OG RENEGATER}

I takt med at englændernes handelsvirksomhed i Konstantinopel, Aleppo, Alexandria, Tunis, Tripoli og Algiers ekspanderede, voksede også den muslimske piratvirksomhed. Disse tal kan give en fornemmelse af problemets omfang: I gennemsnit 70-80 engelske skibe blev årligt berørt af muslimske piratangreb i årene 1592 til 1609, 466 engelske skibe blev angrebet og besætningen solgt som slaver fra 1609 til 1616, 12.000 englændere blev holdt i fangenskab i Barbaresk-staterne mellem 1600 og 1642. Alene i 1625 menes 4500 engelske søfolk at være blevet holdt som fanger eller slaver. Et ukendt antal af disse valgte at tage imod tilbuddet om at konvertere til islam og slå sig ned i en af de nordafrikanske havne, hvor engelske søfolk og skibsbyggere var i høj kurs (Davis 8-10). Samtidig blev de engelske kyster angrebet, og i 1617 blev et tyrkisk piratskib pågrebet langt oppe i Themsen. Men pirateri var som bekendt ikke kun noget 'onde' muslimske pirater udsatte 'hæderlige' kristne handelsfolk for. Tværtimod stod det ethvert skib eller enhver flåde frit for at angribe og plyndre et skib, der sejlede under fremmed flag, ligesom pirater udstyret med kongeligt kaperbrev udgjorde en del af de fleste europæiske landes maritime militærstyrke. Men den nordafrikanske pirattrussel synes alligevel at have været i en klasse for sig. Både kronen og the Levant Company brugte enorme økonomiske, militære og diplomatiske ressourcer på at få sultanen og Barbaresk-staterne til at stoppe piratangrebene - men forgæves. Selvom den engelske Levanthandel reelt var indbringende, betød de hyppige piratoverfald og de mange slavegjorte englændere i Tunis, Algiers og Triopli, at folk både uden for og inden for selskabet betragtede handel med tyrkerne som både umuligt og farligt (Forman 161).

Mens de menneskelige og økonomiske tab, som piraterne påførte de engelske handelskompagnier, udgjorde et konkret og reelt problem, 
betragtedes de kristne tilfangetagne, der valgte at konvertere til islam og således blive renegater, som en moralsk og religiøs skandale. Det vides ikke, hvor mange renegater der opholdt sig i Nordafrika, men franske, engelske, spanske, italienske og skandinaviske fangenskabs- rejseberetninger fortæller samstemmende, at antallet af renegater oversteg antallet af indfødte muslimer i byer som Tunis og Algiers. I en periode, hvor privilegier standsede social mobilitet og hvor enhver stor europæisk by havde titusindvis af fattige indbyggere, kunne emigration til de islamiske dele af verden og konvertering til islam være en måde at starte et nyt og bedre liv på (Kamen 387).

Robert Dabornes tragedie A Christian Turned Turk baserer sig på den legendariske, engelske pirat John Wards historie. Ward, der var ud af en fattig fiskerfamilie fra Kent, var kaptajn på et engelsk handelsskib, da han i 1606 slog sig ned Tunis. Efter at være konverteret til islam i 1610 blev Ward - nu med det tyrkiske navn Reis - en af byens magtfulde og velhavende pirater. I forsøget på at forklare, hvordan det kunne gå så galt, udstyrer Daborne Ward med en idé om menneskets 'frie vilje'. Mennesker styres ikke af forsynet og kan ikke sammenlignes med de ubevægelige himmellegemer, lyder det fra Ward: "Forskellen er: / De [himmellegemerne] er begrænset; det er vi ikke. De er fiksstjerne. / Vi bevæger os".... Dabornes Ward tror på mennesket som en dynamisk, mobil skabning, der former sin egen skæbne. Og: "Kun han fortjener magt og ære / Som modigt plukker sin skæbne fra Lykkens hjul..." Hvor visse folkelige ballader fremstiller Ward som en gemen forbryder og sodomit, udstyrer Daborne ham altså med en vilje til at bryde op fra den lille fiskerby i Kent og indfri en højere ambition, end hans ydmyge byrd umiddelbart tillader. Skuespillet forlener dermed karakteren med ét på en og samme gang heroisk og blasfemisk (over)mod.

Det er kombinationen af mod, begær og ærgerrighed, der får Ward til at give efter for stykkets rige jødiske købmand og guvernør, da de forsøger at overtale ham til - som de siger - at smyge sig fri af "troens slavelænker" til fordel for "Livet, friheden / Rigdommen, æren..." Jøden og guvernøren, der begge selv er renegater, lover Ward, at han kan blive sultanens admiral eller Tunis' nye guvernør. Englænderen lader sig dog først helt overtale, da man også lover ham Voada - ligeledes renegat - som hustru. Lykkelig udbryder Ward nu: 
For at sammenfatte min lykke:

den jordiske gud, over for hvem alle står nøgne, Guldet, som vogter døren til storhed, er min lakaj.

Jeg har mere, end hvad jeg kan bruge. [...] Jeg

vil hellere lede slaver

End være underkastet kongers magt.

Skønhed, magt og rigdom - det er disse tre ting

Hele verden jagter, og de følger mig.

(Daborne 194-95)

Wards ærgerrighed rækker videre end til den materielle rigdom. Født som en af de laveste undersåtter i et hierarkisk samfund mangler han politisk magt og anseelse. Begge dele - plus skønhed - vil blive ham skænket, hvorfor den forestående konvertering indgyder Ward en berusende følelse af frihed og myndighed. Tro er jo i sidste instans blot overtro, der slavegør mennesket:

Menneskehedens slaveri, hvor denne tro dog tyranniserer os!

Berøver os vor frihed lige fra vuggen,

Lænker os til overtroens trældom

(Daborne 195)

Gennem Ward formulerer Daborne en forståelse af tro, der lyder som en foregribelse af den radikale oplysnings religionskritik. At konvertere til islam fremstilles således ikke som et spørgsmål om at skifte tro, men som det at vriste sig løs af en overtros umyndiggørende lænker.

Wards konvertering til islam opføres efterfølgende på scenen. Så vidt vides findes der ikke tilsvarende omvendelsesscener i andre kristne dramaer - der var med andre ord ikke tale om hverdagskost. Indledningsvist beklager det kor, som pludselig træder ind på scenen, at omvendelsen har fundet sted i virkeligheden. Koret advarer om, at publikum skal overvære en handling af en så skamløst gudsbespottende karakter, at den ikke kan siges med ord, men må vises som "a dump show" - en pantomime. Regibemærkninger beskriver herefter dramaturgien i den pantomimiske fremstilling, der tyder på inspiration fra tidens fangeskabsberetninger. Koret udlægger efterfølgende scenen og bedyrer, at alle, der måtte forledes til at se Ward som heldig, vil sande, at han ved at konvertere har givet afkald på den sande lykke til fordel for en ussel og skændig lykke. Publikum vil i det følgende sande, at "de mørke gerninger fører til mørket." Og ganske rigtig. 
I raseri over Wards konvertering sætter hans partner, den hollandske pirat Dansiker, ild til Wards skibe og bygninger i havnen. Berøvet sin formue må Ward ty til tiggerstaven, hvad hans hustru, Voada, der viser sig at være prostitueret, imidlertid ikke vil tage til takke med, hvorfor hun ophæver ægteskabet. For sent sander den gudløse Ward: "At en hånd kontrollerer vores vilje og skæbne". At fornægte forsynet ved at tro på menneskets frie vilje indebærer også at fornægte Guds overmagt og menneskets forpligtelse til lydigt at indtage sin plads i den guddommelige orden. For dette blasfemiske overmod straffer Gud den skændige og skurkagtige renegat, der i næste nu kastes i fangekældrene beskyldt for mordforsøg på Voada. Inden Ward underkastes tortur, begår han imidlertid selvmord ved at stikke en kniv i hjertet på sig selv. Med det ene ben i graven advarer han andre mod at lade sig forføre af tyrkernes og de nordafrikanske piraters "løgne, forførende løgne", da de ikke fører til andet end slaveri og fortvivlelse. Mens skuespilleren fremsagde denne slutsaldo, levede den virkelige Ward alias Reis i bedste velgående i Tunis.

Prologen til A Christian Turned Turk hævder, at dramaet - i modsætning til andre fremstillinger, der har fokuseret på karakterens sociale opstigning - vil skildre essensen af Wards skurkagtighed: Hans omvendelse til islam. Da samfundsordenen defineres gennem en analog relation til den kosmiske, gudskabte orden, er spørgsmålet imidlertid, om den religiøse 'ustandhaftighed' tyder på mere skurkagtig end det at realisere sociale ambitioner. Inden for rammerne af en statisk og hierarkisk samfundsforståelse kan det individ, der bevæger sig ved egen kraft, idet det begærer mere og andet, end hvad det har fået i kraft af sin byrd, og idet det overskrider grænser - symbolske såvel som geografiske - for at tilfredsstille sin ærgerrighed, ikke fremstilles positivt. Eller rettere: hvis A Christian Turned Turk på den ene side udtrykker en fascination for Wards eventyrlige bedrifter, så kan det på den anden side alligevel kun fremstille disse som udtryk for en blasfemisk, irreligiøs og dermed syndig selvhævdelse. Godt nok vækkes den kristne tro til live i den ellers så forhærdede pirats sidste øjeblik men stykket lader ham ikke vende tilbage til de levende kristnes rækker. Hvor The Jew of Malta på den ene side straffer den troløse Barabas, men på den anden side lader hans rænkespil komme de kristne til gode, bruger $\mathrm{A}$ Christian Turned Turk sin problematiske hovedperson til et mere entydigt formål: Historien om Ward tjener til skræk og advarsel. 
Den anti-islamiske propaganda i A Christian Turned Turk lyder som et ekko af de prædikener, kirken udsatte engelske sø- og handelsfolk for, og hvori der blev advaret mod fristelsen til at konvertere til islam (Vitkus, Three Turk Plays from Early Modern England 6). Uanset en vis fascination for Wards mod minder stykket om, at man ikke må sætte egen vinding over loyaliteten mod kirke og konge, heller ikke når man befinder sig ude i den store verden, langt borte fra kongens og kirkens jurisdiktion. Mens stykket således på den ene side lader Ward klandre det statiske kristne samfundssyn for at spænde ben for driftige menneskers foretagsomhed og lykkedrift, fremstiller stykket på den anden side det samfund (Tunis), hvori den enkelte får lov til at udfolde sin driftighed, som dysfunktionelt, depraveret og retsløst. Folk, der sætter sig op imod "himmellegemernes ubevægelige orden" og smeder deres egen lykke, sådan som stykkets renegater har gjort, fremstår som upålidelige, egoistiske og manipulerende. Og Ward selv - den sociale opkomling par excellence - er selvfølgelig også alt andet end ren i kanten.

Hverken Marlowe eller Daborne kunne forestille sig, hvad Adam Smith godt og vel 150 år senere så for sig i The Wealth of Nations (1776), nemlig at der kunne være en utilsigtet positiv virkning for 'de mange' forbundet med en situation, hvor enkeltindivider frit kan disponere med deres egen fordel for øje. Endnu troede man, at denne situation førte til kaos. Den Smithske teori, der ofte henvises til som ideen om "den usynlige hånd", findes heller ikke i Massinger's Renegado, men til forskel fra både The Jew of Malta og A Christian Turned Turk forsyner denne tragikomedie markedet og handelsvirksomheden med en kristen dimension. Hvis the merchant forstås som en person, der sikrer forsyningen af varer til den markedsplads, hvortil i princippet alle har adgang, kan the merchant ikke beskyldes for kun at arbejde for sin egen fordel. Problemet er imidlertid, at tyrkerne ikke respekterer dette flow og dermed heller ikke den tilgængeliggørelse af varerne, som markedspladsen udvirker.

\section{BEFRIELSE}

I Massingers tragikomedie The Renegado, der foregår skiftevis i basaren i Tunis og i den tunesiske vicekonges palads, iscenesættes en konfrontation mellem en tyrkisk-orientalsk henholdsvis en vestlig merkantil orden. 
Hvor den orientalske orden dårligt kan kaldes merkantil, eftersom den i skuespillet associeres med despoti, røveri, overforbrug og en illusion om ubegrænsede ressourcer, forbindes den vestlige merkantile orden med kundens frihed til at købe varer og sælgerens forpligtelse til at lægge til side til $\mathrm{k} ø \mathrm{~b}$ af nye varer for dermed at sikre vareforsyningen til markedet. I The Renegado ødelægges dette flow af pirat-renegaten Grimaldi og den tunesiske vicekonge Asembeg. For så vidt tegner tragikomedien jf. ovenfor et ganske realistisk billede af Levant Kompagniets problemer med de nordafrikanske piratangreb og med de osmanniske såvel som de lokale (tunesiske eller algeriske) myndigheders utilbøjelighed til at gribe ind over for piraterne. Humlen ved det hele var naturligvis, at de lokale myndigheder fik procenter af piraternes rov, akkurat som den tunesiske vicekonge Asembeg gør i The Renegado.

$\mathrm{Nu}$ kobler The Renegado imidlertid endnu en konkret, historisk problemstilling til ovenstående, nemlig befrielsen ("the redemption") af de kristne - in casu den skønne Paulina - som piraterne tog til fange, og som de lokale beyer, janitsharer og andre myndighedspersoner tjente penge på, idet de enten solgte dem på slavemarkedet eller opkrævede løsepenge af familie, slægt eller kirke i den tilfangetagnes hjemland. Asembeg, der lever af Grimaldis plyndringer, har spærret Paulina inde på sit palads, hvor han ihærdigt - men forgæves - forsøger at besejre hendes dyd, og i stykkets begyndelse ankommer hendes bror, den venezianske adelsmand ved navn Vitelli, til Tunis ombord på et handelsskib for at "redeem", befri, hende fra den vellystige despot. Forklædt som købmænd har Vitelli og hans tjener Gazet opnået "lov til at handle frit", og i en bod i byens basar sælger de nu venezianske similivarer.

"To redeem" betyder at løskøbe, genvinde, befri fra fangenskab, trældom og straf, redde og frelse (Forman 153). Både i den katolske og den protestantiske verden var kristnes befrielse fra muslimsk fangenskab eller slaveri, hvad end denne nu skete gennem løskøb eller gennem flugt, ladet med religiøse konnotationer som forløsning, udfrielse og frelse. Den befriede kristne var frelst i betydningen reddet fra at falde for islam. I et større symbolsk perspektiv markerede befrielsen derfor, at Gud havde sejret over Allah. Befrielsen betød således ikke bare, at slaven blev genforenet med Gud. Den betød også, at kristendommen blev styrket. I The Renegado asso- 
102 KULTUR \& KLASSE * $124 * 2017$

HANDEL

cieres markedspladsens lokkende udbud af varer med en frisættelse af et begær, som den tyrannisk-islamisk-patriarkalske overmagt ellers har taget monopol på. På markedspladsen foregår der en tilgængeliggørelse af varer til det fælles bedste så at sige, hvilket står i skarp kontrast til piraten, der lader de varer, som ellers er på vej mod markedet, forsvinde ned i sit eget og sin herres, den tunesiske vicekonges, private forbrugs sorte hul. Men hvad har markedets frihed med den kristne befrielse eller frelse at gøre?

\section{MARKEDET OG TYRANNIET}

Den osmanniske Donusa, der henslæber en kedsommelig tilværelse overvåget af eunukker på sin onkel Asembegs palads, fungerer som et vigtigt talerør for skuespillets kritik af det orientalske tyranni. Donusa kalder Asembeg for:

... en tyran,

En umættelig epikuræer

der svælger i sin egne nydelser, som han krammer så kærligt,

Holder så fuldstændigt og aldeles for sig selv,

[samtidig med at] han ikke tillader andre selv et mådeholdent forbrug ["use"]

Af nydelse

(Massinger 313)

I dette tyranni spærres kvinderne inde af "jaloux tyrkere", der "aldrig tillader at deres skønne koner bliver set/ bortset fra på badeanstalterne eller i moskerne / Og da kun når de er tildækkede og under bevogtning" (Massinger 255), som Donusa siger, mens hun giver udtryk for misundelse af de engelske kvinder, der - har hun hørt - tilstås større frihed af deres mænd. De tyrkiske kvinders begær, forklarer den jesuitiske præst Francisco, der også opholder sig i Tunis med henblik på at frikøbe kristne fanger, kan sammenlignes med engelske mastiff-hunde, hvis glubskhed forstærkes af lænker, hvorfor Vitelli bør være på vagt, når han åbner sin bod. Det begær, som de jaloux tyrkiske mænd undertrykker i deres kvinder ved at holde dem indespærret, kan nemlig få frit løb blandt basarens varer og handlende. På markedet findes endvidere et alsidigt udbud af forunderlige varer fra alle egne af verden, som Donusas krigertamp af en bejler - Mustafa, pashaen af Aleppo - konstaterer, dog uden begejstring. Her mødes alle nationer, 
og hele denne alsidighed ("variety") vækker også Donusas lyst: "Jeg føler en jomfruelig lyst til at gå ned [på markedet]", ikke "for at købe men for at kigge på /de forunderlige varer", bemærker hun. Markedet udgør med andre ord ikke bare et sted, hvor man køber det, man har brug for, det repræsenterer også et sted, hvor man hengiver sig til et mere diffust voyeuristisk begær. Modstræbende følger pashaen med ned i basaren, hvor Donusa straks tiltrækkes af varerne i Vitellis bod. Da varernes og kroppenes tiltrækningskraft, købelyst og seksuel lyst, smitter af på hinanden i dette skuespil, river Donusa sløret af sit ansigt for at forføre Vitelli med sin skønhed. I samme nu knuser hun (forsætligt) et glas, og da hun ikke har medbragt penge, har hun nu gjort sig selv til hans "debitor". Donusa benytter med andre ord kreditten eller gælden til at skabe et bånd mellem sig selv og Vitelli, og da venezianeren kort efter ankommer til paladset for at indkassere sine penge, overøser Donusa den overrumplede italiener med en lind strøm af seksuelle ydelser, mønter og indiske perler. Denne pludselig uhindrede adgang til nydelse og rigdom forvandler imidlertid Vitelli. Du er, siger Franciso, der kender Vitelli fra Venedig, "mærkeligt forandret" [...] Du har, Herre, været på / En indbringende rejse - lade os bede til Himlen at den også har været anstændig" (Massinger 283). Den materialistiske Gazet ser mere lyst på sin herres indbringende rejse. Med begejstring konstaterer han, at Vitelli kaster om sig med guld: "han er så fri / og gavmild med sit guld. Ha, drømmer jeg/ Eller er dette virkelig min herre?" (Massinger 283) spørger Gazet, hvorefter han henvender sig til Vitelli med ordene: "Du var for et øjeblik siden / i det gavmilde hjørne og kunne måske tænke på Gazet..." Venezianerens forvandling til et ødeland indebærer også, at han er på nippet til at konvertere til islam: "Jeg tror han er fortabt", konstaterer Francisco ved synet af de dyre tyrkiske klæder, som Vitelli spankulerer rundt i. Mens det internationale handelsmarked (for en stund) altså har befriet den osmanniske prinsesse fra tyrannens fængsel, har det bragt Vitelli i kontakt med ubegrænsede ressourcer, der - vel at mærke - kun er ubegrænsede, fordi de i sidste ende stammer fra Grimaldis piratvirksomhed. Det særlige ved piratvirksomheden er, at den udgør et 'behageligt' modstykke til den legitime handelsøkonomi. Som Grimaldi svarer, da en af hans kumpaner foreslår, at de ikke bruger alle deres penge på sex og sprut, men gemmer lidt til senere: 
104 KULTUR \& KLASSE * $124 * 2017$

HANDEL

Død over sparsommeligheden!

Når dette er brugt, har vi så ikke stadig vores skibe

Og vores mod til at få fat i noget mere?

[...]

$[\mathrm{H}]$ avet, vores moder (der favner begge de rige Indien'er med sine udstrakte arme),

Avler hver dag en ny afgrøde som det kun kræver mod at høste [...]

Nej, nej, kammerater! Lad handelsmanden om at spare op

Og ågerkarle om at samle til bunke. Lad vores udgifter

Være som vores indkomster - grænseløse

(Massinger 261-2)

Spottende sammenligner Grimaldi den ærlige handelsmand, der udviser mådehold og lægger til side med en gnierisk ågerkarl. Piraten, der har ubegrænsede ressourcer, kan tillade sig at være stor i slaget og forbruge umådeholdent her og nu.

Det orientalske tyranni, der med piratens hjælp tvinger varestrømmen i tyrannens retning, repræsenterer en obstruktion af det flow af varer, som holder den internationale handelsaktivitet i gang. Den enes ubegrænsede forbrug umuliggør udvekslingen af varer og penge mellem alle. Som det fremgår, når Gazet falbyder sin herrers varer, henvender markedet sig til alle, mand som kvinde, høj som lav:

Hvad mangler De? De kan vælge mellem kinesiske tallerkner, Vores rene venetianske krystal af alle slags, mellem pæne og nye Modevarer, alt lige fra spejle til fruen til stuepigens egne køkkenredskaber [...] Hvad mangler I, gentlemen?

(Massinger 259)

Dertil kommer, at markedet - som nævnt - har en international dimension. Markedspladsen danner med andre ord ramme om møder på tværs af sociale og nationale grænser, hvilket gør det både dragende og farligt - forstår man. Selvom basaren i Tunis altså udgør en markedsplads, hvor sociale og nationale forskelle overskrides, synes det alligevel som om, at denne i så henseende er mere kristen end orientalsk. I hvert fald fremstår det at udstille varerne, så de behager og lokker køberne til, som en særlig kristen skik: "Er det den måde de kristne/ sælger deres varer?" spørger Donusa, da hun forbløffes over de mange varer, der ligger og byder sig til i Vitellis bod. Dette at lægge varerne frem til alles beskuelse og således gøre 
dem tilgængelige for alle, der vil betale, fremstilles i The Renegado som en særlig kristen merkantil praksis.

\section{MARKEDET OG DET FÆLLES BEDSTE}

Markedet repræsenterer således et frirum, hvor enhver har adgang til at nyde og købe. Men markedet eller handelsvirksomheden forbindes også med nogle af de mere tvetydige og negative betydninger, som vi har set i det foregående. Dét pludselig at være merchant vækker eksempelvis en religiøs pragmatisme til live i Gazet: "Jeg vil ikke lade mig begrænse / af min tro [...] Når jeg lever i England, Spanien, Frankrig, Rom eller Geneve, / sværger jeg til det pågældende lands tro" (Massinger 250). Det eneste, der forpligter Gazet i hans rolle som købmand, er "min herres fortjeneste". Også adelsmanden Vitelli smittes af markedets frirum, og de møder henover kønnets, hierarkiets og troens grænser som det muliggør. Det er på markedspladsen, at Vitelli lokkes ud på "en indbringende rejse" til Donusas gemakker. Det er til markedspladsen, Vitelli vender tilbage for at kaste sig ud i et ukristeligt, islamisk-orientalsk overforbrug. Markedspladsens politiske, religiøse og moralske frirum åbner på en og samme gang for sanselighedens frisættelse og identitetens fremmedgørelse.

Det særlige ved The Renegado er nu, at dette marked også fungerer som en vej til befrielsen og frelsen af Paulina. Det var i hvert fald Vitellis plan, indtil det viser sig, at markedet i stedet bliver katalysator for hans eget overforbrug og (aldrig fuldbyrdede) omvendelse til islam. Men det ender med, at Paulina befrier sig selv, fordi Vitelli selv ender i despotens fængsel på grund af sit ifølge osmannisk lov - gudsbespottende forhold til den muslimske Donusa. Her får han valget mellem at dø eller at konvertere til islam og blive gift med Donusa. Hvor det i udgangspunktet handlede om Paulinas befrielse fra islam, kommer skuespillet således til at handle om Vitellis omvendelse til islam via Donusas krop og guld. Grimaldi er således ikke stykkets eneste renegat - Vitelli er ganske tæt på også at blive renegat. Da det kommer til stykket, udviser den unge adelsmand imidlertid standhaftighed i troen, hvad der også får Donusa omvendt til den kristne tro. Alle, der har været indespærret, befries til sidst, og ombord på den genkristnede Grimaldis skib forlader Paulina, Francisco, Vitelli og Donusa nu Tunis med kurs mod Venedig. 
106 KULTUR \& KLASSE * $124 * 2017$

HANDEL

The Renegado forsøger at få markedet, handel og befrielse i kristen forstand til at krydse betydninger. Gennem kontrasteringen til Grimaldi og Asembeg implicerer skuespillet et ideal om den gode merchant, der fodrer markedet således, at alle har adgang til varer - i modsætning til piraten og hans tyranniske bagmand, der kanaliserer varestrømmen væk fra de mange og i retning af dem selv. Når den gode merchant giver afkald på selv at forbruge for i stedet at forsyne det marked, hvor alle kan nyde og købe, opfører han sig som den gode kristne, der udviser standhaftighed over for fristelsen til at redde sit eget livet ved at konvertere til islam. Sigende nok indebærer Grimaldis genkristning et løfte om, at han fremover vil bistå kristne handelsskibe med at forsvare sig mod piratangreb. Grimaldi ofrer således det personlige forbrug til fordel for en sikring af varernes flow. På samme måde sikrer den kristne, der foretrækker døden frem for omvendelse til islam, den kristne tro. I The Renegado peger Massinger således på, at der også findes en moralsk ansvarlig og kristen måde at være handelsmand på, hvor markedspladsens eller markedets - og ikke the merchants - interesser er styrende.

\section{KONKLUSION}

De tyrko-barbareske skuespil har træk til fælles med de samtidige merkantile komedier, der med en blanding af fascination og foruroligelse skildrer de friere og mere individualistiske sociale, moralske og økonomiske udvekslinger i og omkring den internationale handelsbørs i London, The Royal Exchange. Men fordi de orientalske merkantile dramaers personer befinder sig uden for de nationale, magt- og norminstansers rækkevidde i en langt mere radikal forstand end de handlende på The Royal Exchange, antager friheden og individualismen langt mere radikale former. De dramaer, som er blevet analyseret i det foregående, tematiserer den økonomiske interesse som et begær, der har kraft til at underminere det beskyttelsesværn mod islam, som den sande tro ellers skulle udgøre. Begæret efter guld udgør en potentiel glidebane, dets verdslighed og egoisme fører den enkelte på afveje, væk fra eller ud af den sociale, religiøse og politiske orden.

Den europæiske orientalisme har flere historisk, nationalt og socialt distinkte fremtrædelsesformer. En af disse udgøres af den handelsorientalisme, som er blevet behandlet i det foregående. Når man går den vestlige 
orientalismes forskellige fremtrædelsesformer efter i sømmene, hviler ingen af dem i virkeligheden på den entydige Øst/Vest-dikotomi, som Edward Said hævdede. Spejlinger, projiceringer og fascination vidner om porøse grænser, identifikation og genkendelse. Grænsen mellem Øst og Vest, islam og kristendom, må dog siges at være særligt ustabil i den engelske, merkantile orientalisme, hvilket skyldes, at begæret, og ikke ønsket om at besejre eller kristne, udgør den væsentligste årsag til mødet mellem den muslimske og den kristne verden. De tyrko-barbareske dramaer betragter Orienten gennem en bestemt prisme bestående af såvel beundring som mistænksomhed over for det individ, der har kraft til både i social og geografisk forstand at løsrive sig fra den hjemlige ordens hierarkier for at tilfredsstille sin ærgerrighed og økonomiske interesse. Dette særtræk kan også forklare, hvorfor der optræder så mange jødiske karakterer i de engelske tyrko-barbareske dramaer, og hvorfor de fremstår som lige så centrale som tyrkerne. Der levede mange jøder i Det Osmanniske Rige, og ofte fungerede de som go-betweens mellem kristne købmænd og tyrkere. Dertil kom, at de - akkurat som den fiktive Barabas - ofte var koblet op i internationale netværk med andre jødiske købmænd, hvis penge og kontakter de kristne købmænd benyttede sig af. Det, som dramaerne især betoner ved jøden, er hans egoisme og mangel på identitetsmæssig forankring i sociale og politiske hierarkier. Jøden og renegaten udgør således eksempler på tidens forestillinger om den moralske habitus hos individer, der styres af markedskræfter og ikke af kosmiske kræfter, forsynet eller herre-vasalhierarkiet. I de engelske tyrko-barbareske dramaer repræsenterer tyrkerne ikke nogen militær trussel; de er vellystige, grumme og dumme og som sådan ikke genstand for den ærefrygtige, skrækblandede fascination, som de samtidige franske og italienske tyrker-dramaer omgiver tyrkerne med. Tyrkernes tro, islam, fremstilles først og fremmest som en port til verdslig lyst, hvorfor det tidlige moderne engelske drama fremviser disse mange eksempler på merchants, der fristes til at konvertere. Den merkantile orientalisme spænder med andre ord over en kiakisme for så vidt som den 'islamiserer' den merkantile verden og 'merkantiliserer' islam.

ANNE FASTRUP. Lektor ved Institut for Kunst- og Kulturvidenskab, Københavns Universitet. Har bl.a. skrevet Sensibilitetens bevægelse: Denis Diderots fysiologiske æstetik (2007) og en række artikler om repræsentationen af islam og orienten i tidligt moderne europæisk litteratur. 
108 KULTUR \& KLASSE * $124 * 2017$

HANDEL

COMMERCE ORIENTALISM IN ENGLISH DRAMA, 1580-1630

The early modern Turco-Barbary plays of Christopher Marlowe, Robert Daborne and Philippe Massinger bear witness to how deeply England's expanding trade with the Muslim Ottoman Empire affected English literature. Within few decades, a new catalogue of dramatis personae such as Turcs, Barbary pirates, English sailors who had converted into Islam, Jewish merchants and go-betweens, began to appear on the scenes of London's commercial theatres. The purpose of this article is to discuss the particular mercantile character of this renaissance orientalism. Through the demonstration of how the theatrical representation of the encounter with the Muslim world was based on a moral suspiciousness or scepticism toward the merchant whose commerce depended upon foreign markets in goods and money, this article attempts to understand why conversion to Islam and cross-cultural movement becomes such a prominent feature in the English Turco-Barbary plays.

\section{KEYWORDS}

EN: Commerce, orientalism, mercantilism, renegate, islam, market place, pirates, jews, conversion, chartered companies, common-wealth, early modern drama, Turco-Barbary

DA: Handel, orientalisme, merkantilisme, renegater, islam, markedsplads, pirater, jøder, konvertering, handelskompagni, det fælles bedste, tidlig moderne drama, tyrko-barbaresk

\section{LITTERATUR}

Davis, Robert C. Christian Slaves, Muslim Masters, White Slavery in the Mediterranean, the Barbary Coast, and Italy, 1500-1800. Hampshire and New York: Palgrave Macmillan, 2003.

Erikson, Emily og Valentina Assenova. "Introduction: New Forms of Organization and the Political and Commercial Actors". Red. Emily Erikson. Chartering Capitalism: Organizing Markets, States, and Publics. UK: Emerald Group Publishing Limited, 2015. 1-15.

Finkelstein, Andrea Lynne. Harmony and Balance: An Intellectual History of Seventeenth Century English Economic Thought. USA: University of Michigan Press, 2000.

Forman, Valery. Tragicomic Redemptions: Global Economy and the Early Modern English Stage. Pennsylvania: University of Pennsylvania Press, 2013. 
Games, Alison. The Web of Empire: English Cosmopolitans in an Age of Expansion, 1560-1660. Oxford: Oxford University Press, 2008.

Greenblatt, Stephen. "Marlowe, Marx, and Anti-Semitism". Critical Inquiry 52 (1978): 291-307.

Kamen, Henry. The Iron Century: Social Change in Europe, 1550-1660. New York: Prager, 1971.

Levin, Richard. "The Contemporary Perception of Marlowe's Tamburlaine". Medieval \& Renaissance Drama in England 10 (1998): 51-70.

Marlowe, Christopher. Jøden fra Malta. Loxodonta.dk 2016.

Marlowe, Christopher. Tamburlaine Den Store, del 1. Loxodonta.dk 2016.

Said, Edward. Orientalism. London: Penguin Books, 2003.

Thurn, David H. "Economic and Ideological Exchange in Marlowe's "The Jew of Malta". Theatre Journal 462 (1994): 157-170.

Vitkus, Daniel J. (red.). Three Turk Plays from Early Modern England: Selimus, Christian Turned Turk, The Renegado. New York: Columbia University Press, 2000.

Vitkus, Daniel. "Turning Turk in Othello: The Conversion and the Damnation of the Moor". Shakespeare Quarterly 482 (1997): 145-176. 
110 KULTUR \& KLASSE * $124 * 2017$ HANDEL 